\title{
EVALUATING THE LEVEL OF UNETHICAL BEHAVIOR BY QUANTITY SURVEYORS IN THE NIGERIAN CONSTRUCTION INDUSTRY
}

Ebunoluwa Bimbola Akinrata ${ }^{1}$

${ }^{1}$ Department of Quantity Surveying, Ahmadu Bello University, Zaria-Nigeria.

\section{*Corresponding Author: Ebunoluwa Bimbola Akinrata \\ Corresponding Author Email: akinrataebun@gmail.com}

Article Received: 20-07-19 Accepted: 25-08-19
Published: 05-09-19

Licensing Details: Author retains the right of this article. The article is distributed under the terms of the Creative Commons Attribution-Non Commercial 4.0 License (http://www.creativecommons.org/licences/by-nc/4.0/) which permits non-commercial use, reproduction and distribution of the work without further permission provided the original work is attributed as specified on the Journal open access page.

\section{ABSTRACT}

Construction industry is one of the main drivers of financial development in many countries not leaving out Nigeria. The industry faces a long rundown of ethics/moral difficulties identified with practices from its professionals. So therefore, the supposition study of this report demonstrated that there is basic conduct of concern with respect to unethical practices among Quantity Surveyors in Nigerian construction industry. The motivation behind this paper is to evaluate the level of unethical conduct among Quantity Surveyors by featuring most normal unethical conduct by Quantity Surveyors in their administrations conveyance in the Nigerian construction industry. Questionnaires enumerating 21 unethical practices by Quantity Surveyors which were sent to professionals in construction firms within the Nigerian construction industry to assess. Altogether, 114 legitimate reactions were investigated by mean item score and exploratory factor analysis. In view of the mean score, "Supplanting", "Concealing of professional errors" and "Conflict of interest" are the most widely recognized unethical behaviour and conduct of Quantity Surveyors in their administrations conveyance in the investigation territory. From the aftereffects of factor analysis, six main practices were extracted, these are: Dishonesty, Insincerity, Financial mismanagement, Information leaking, Negligence, and Conflict of interest. While this study fills in as significant wellspring of reference for general learning on ethical behavior and moral conduct of Quantity surveyors in construction industry. The methodology utilized in this study can be replicated by different professionals in the construction industry like Architect, Contractors, Builders and the Engineers. This can likewise be duplicated in different areas for further studies. Moreover, further studies may utilize more techniques in gathered the information. . For this study, only questionnaire survey is utilized. Using several techniques will make the outcomes more adaptable and precise. Method such as interview, comparing data and many more can be adopted, this may explore the connections between the principal factors and their related factors. This study has given valuable data with respect to unethical conduct by Quantity Surveyors. However, the restriction is characteristic in the number of respondents in the investigation which is 
constrained just to the exploration zone. This study will be important wellspring of reference for general learning on ethical conduct of Quantity surveyors in Nigerian construction industry for researchers and various stakeholders in the industry. This study will be advantageous to all relevant parties that associated with the construction industry extending from those engaged with scholastic research, understudy and experts in the construction industry. The result introduced in this study give adequate confirmation and valuable pointers to illuminate a few confusions about unethical conduct in the construction industry.

Keywords: Unethical Behavior, Quantity Surveyors (QS), Factor Analysis, Construction, Professional.

\section{INTRODUCTION}

Quantity surveying as a profession is a combination of few other disciplines within an exceptional setting. It grasps financial matters, law, administration, measurement, contract management, data innovation, accountancy, construction and et cetera, all within the system of construction industry. The roots of its techniques are about dependably be found inside these different trains yet adjusted to the specific needs of its construction customer base (Brandon, 1990). Quantity surveyors (QS) add esteem essentially to the budgetary and legal binding administration of construction ventures at the preconstruction, construction and post construction stages. They contribute to general construction project execution in the construction industry (Nkado and Meyer, 2001). The Quantity Studying Profession is saddled with the cost responsibility of the construction industry. The training is regulated and managed in Nigeria by the Nigerian Institute of Quantity Surveyors (NIQS) and the Quantity Surveyors' Registration Board of Nigeria (QSRBN).

Ethics are moral rules that guide or impact a man's conduct, exercises and directions. It is worried about separating between what is good and bad. Ethics essentially looks to determine the inquiries in managing human profound quality. Ethics involve in human concept \& ideas like, good and bad, great and terrible, satisfactory and unsuitable, self-interests and narrowmindedness. The construction industry is all around respected all through the world for being brimming with great, rational and genuine individuals and professionals (Vee and Skitmore, 2003). As indicated by Nawaz and Ikram (2013), building professionals have picked up trustworthiness and respectability through professional bodies. In Nigeria, such professional bodies like Nigerian Institute of Quantity Surveyors (NIQS), Nigerian Institute of Architects (NIA), Nigerian Society of Engineers (NSE), Nigerian Institute of Town planners (NITP) and others, enforce/authorize professionalism within the Nigerian construction industry. The professional norms and ethics are encapsulated in codes of training which characterize the commitment of professionals. Poon (2005) uncovered that all professionals have their codes to direct the training and trustworthiness of the professions. The requirement of codes of ethics by professional bodies will go far in diminishing unethical practices in Nigeria, this is in accordance with the meaning of professional ethics by RICS (2001), which is the act of giving one's best to guarantee that customers intrigue are legitimately administered to, while more extensive open intrigue is likewise appropriately perceived and secured. The professional codes of ethics might be believed to fill in as keeps an eye on the exercises of the individual members of a profession. Be that as it may, they likewise serve in shielding the members from risk for carelessness, and the enthusiasm of the clients. 
There is a developing accord inside and outside the construction industry that defilement and other unethical practices are endemic in the construction industry (Ameh and Odusami, 2005). At the point when construction processes including accounts are not executed in a professional and moral way, at that point QS engaged with the procedure may have away to hone unethical and unprofessional acts, this truly harms the profession. So also, there have been instances of ineffectively and substandard built structures in many parts of the country. In addition, this inaction and toleration of unethical practices among the professionals in the construction has prompted different abused or wasteful utilization of project reserves. Which in the end, the final result has all the earmarks of being deficient, substandard, insufficient and risky (Nawaz and Ikram, 2013). These events and impacts of moral unfortunate behavior by Quantity Surveyors have set off various investigations identifying with unethical practices in the construction industry not leaving out this study.

Construction projects have experienced under-accomplishment in the current past, this is on the grounds that professional's misconduct has been on the expansion in the construction industry (May et al., 2001). Despite the fact that the construction industry is one of the key drivers of monetary development in numerous nations, the industry faces a not insignificant rundown of moral difficulties identified with conduct from its professionals which incorporates; offer shopping, installment diversions, lying, problematic contractual workers, claims amusements (e.g. swelled cases, false claims), risks, irreconcilable circumstance, conspiracy, extortion, and professional carelessness (Ho, 2011). Ethics have an irrefutable impact on the believability and monetary maintainability of quantity surveying practices and also influencing the individual security of the profession. Along these lines, this paper expects to distinguish and evaluate the unethical practices and conduct of Quantity Surveyors in their administrations conveyance within Nigerian construction industry. The paper displays an academic and handy way to deal with ethical evaluation of Quantity Surveyors in the construction industry in an approach to improve moral standard among them. It will likewise fill in as significant oasis of reference for general information on ethical conduct of Quantity Surveyors and other professionals in Nigerian construction industry for researchers and various stakeholders in the industry.

\section{LITERATURE REVIEW}

\section{Ethics}

Paswan (2010), ethics is gotten from the Greek word 'ethos' which implies a man's basic introduction toward life. Ethics might be characterized as a hypothesis of profound quality which endeavors to systematize moral judgments. As per Garret, "Ethics is the study of judging particularly human ends and the relationship of intends to those ends". Somehow, it is additionally the specialty of controlling means so they will serve particularly human closures. In this manner, ethics is the art of judging good and bad in human relationship. It can likewise be named as the "investigation of character of a man" communicated as right or wrong lead or activity. As indicated by the Oxford English Dictionary, "ethics" is all of which identify with morals that is 'the entire field of moral science, moral standards or code. Robinson, Dixon, Preece and Moodley (2007) saw ethics as a philosophical investigation of what is correct or wrong in human lead and what standards or rules ought to represent it. Maybe the definition 
which is most apropos is, 'The moral standards or arrangement of a specific pioneer or school of thought; the moral standards by which a specific individual is guided; the guidelines of conduct perceived in a specific calling or zone of human life'. Bowen et al., (2007) presented that ethics isn't just about perceiving whether a goal is great yet but includes a cautious idea in settling on feasible decision or recognizing if the decision is correct or off-base. Wasserman (2000) expressed that, ethics isn't just about perceiving a goal decent. It contains an investigation of thought, dialect, thinking, procedures and judgment that educates the decisions individuals make in their day by day experience that influence their own prosperity and that of others. Vee and Skitmore, (2003) clarified further that, it is presently ordinarily perceived that the general ideas of ethics are applicable in business, in light of the fact that organizations exist not exclusively for the advantage of specific people, but rather on the grounds that business serves society all in all, and likewise, meets group and individual needs. Ethics in Quantity surveying profession is a considerable issue and assumes a fundamental part in project achievement. Ethics is essential; on the grounds that by it, Quantity surveyors can position themselves inside the web of interrelationships among different gatherings in an undertaking domain (Mondejar et al., 2007). Ethical infringement in construction has never been on the first page of the daily paper, yet they happen each day. By and large, they cause certifiable issues for owners and additionally numerous great organizations that decline to take part in the sorts of unethical preconstruction obtainment exercises of their potential clients and general temporary workers (Miller, 2011). Ethics have an unquestionable impact on the validity and monetary supportability of quantity studying rehearses and in addition influencing the individual security. Professional ethics these days is considered as a prominent point inside the construction industry (Mason, 2009). Moral conduct among Quantity surveyors is a subject seldom talked about straightforwardly, likely in light of the fact that for the vast majority include are as embodiment of tossing stones in a glass house. The reality of the matter is that the Nigerian construction industry is the key driver of ethics administration and financial development in the nation, however shockingly the industry faces an extensive rundown of moral difficulties identified with conduct including: offer shopping, installment diversions, lying, inconsistent temporary workers, claims recreations, false claims, swelled cases, dangers, arrangement, irreconcilable circumstance, extortion, and professional carelessness.

\section{Unethical Conduct by Quantity Surveyors in the Nigerian Construction Industry}

The construction industry is named the most deceitful industry around the world, giving the ideal condition to ethical issues, with its low-value attitude, savage rivalry and paper-thin edges (Hamimah et al., 2012). With respect to the construction industry itself, the ethical contemplations which are essential are necessary, for instance giving cautioning of the catastrophes which must be maintained a strategic distance from. The obligation here is mind boggling and moral issues for this situation must be viewed as (Uff, 2003). The fundamental unethical conduct in the Nigerian construction industry which has been found through writing and productions is "Corruption and Bribery" as indicated by Olusegun et al., (2011). Which is a consider exertion by contenders to plot viably to lift costs where clients purchase merchandise and ventures through contending offers [Abdul-Rahmam et al., (2011); 
Aigbavboa et al., (2016)]. The most frequently reported revealed that unethical practices in the industry is bribery, depicted as: "the offering of some goods, administration or cash to a fitting individual to secure an advantaged and good thought (or buy) of one's item or corporate project" (Vee and Skitmore, 2003). In addition pattern of 'Cover pricing' has brought cautions step up in the construction Industry. In this procedure a bidder presents a value that isn't proposed to win the agreement they are participating. There are different manners by which contending bidders practice this misbehavior. It is possible that they submit cushioned up offer which is outlandish for the acknowledgment, or thump out assigned champ or oblige such terms and conditions that are known to be unsatisfactory to the clients [Babalola and Anifowose (2015); Hamzah et al., (2010); Oyewobi et al., (2011); Olusegun et al., (2011).

Poll reviewed in Australia directed by Vee of and Skitmore (2003) for typical project supervisors, engineers, building contractual workers and others professionals in the construction industry on a scope of ethical issues encompassing construction industry exercises, which demonstrated that every one of the respondents had seen or encountered some level of unethical lead, as unfair conduct, collusive tendering, negligence, conflict of interest, fraud, confidentiality and propriety breach , bribery and violation of environmental ethics, the voracity being one of the primary variables prompting unethical lead. Ameh and Odusami (2010) additionally evaluated the view of construction professionals in moral issues the result shows that the most widely recognized unethical conduct is money related pay off which is financial bribery and furthermore there is awesome weight on construction chiefs to act unethically, professional unfortunate behavior and professional carelessness. Professional moral slips by frequently prompt project relinquishment, capital flight, and immense monetary misfortune as extra cost of projects, which runs, in the vicinity of 40 and $60 \%$ of granted contract entirety. Bribery and political corruption is being tended to sternly and solidly by a few professional bodies, social orders and business bunches far and wide (Mathenge et al., 2012). It is likewise verifiable truth that corruption is the significant issue that torment the industry in creating economies.

As indicated by Ameh and Odusami (2010), bribe is money or non-money support to receive something consequently (e.g. up and coming guarantee of a future contract without following standard strategies, advancement, or a get-away). Fraud and bribery are types of defilement. Amundsen (2000) recognized political and bureaucratic corruption, 'individual' and 'aggregate' types of corruption, and corruption as a component of either 'upward extraction' or 'descending redistribution'. The principle types of corruption recognized are bribery, theft, misrepresentation and blackmail. These ideas are partly overlapping and at times interchangeable with other concepts. Hamra (2000) is of the view that bribery restrains financial improvement and misshapes rivalry. What's more, it disturbs conveyance channels, decimates motivations to contend in quality and costs, undermines advertise effectiveness and consistency and at last denies numerous individuals the privilege to a negligible way of life. Negligence as 'absence of appropriate care and consideration; or indiscretion's is one of the unethical conduct by Quantity surveyors in the Nigerian construction industry. Professionally, this would be the inability to practice the level of care considered sensibly justified by the 
conditions, bringing about unintended damage to another party [Abdul-Rahmam et al. (2011); Aje and Awodele, (2006); Bowen et al.,(2007)]. As indicated by Nawaz and Ikram, (2013), to be negligent, the professional must have had the ability to be competent, however has ignored the significant of practicing this capacity. The negligent professional neglects the strategy which is in the client's best advantage.

Ethical issues in the construction industry not only deal with corruption but as well as conflict of interest and collusive tendering (Hamimah et al., 2012). Vee and Skitmore (2003) consolidate unfairness with dishonesty as the major unethical conduct inside the construction industry. It could be contended that deceptive nature constitutes unlawful conduct and is along these lines all the more fittingly connected to misrepresentation [Nawaz and Ikram, 2013; Abdul-Rahmam et al. (2011)]. Examples cited by Vee and Skitmore (2003) as being 'unfair' incorporate activities by government offices, such as, 'one-sided offering assessment framework, the process of re- tendering and shopping for prices after tenders have closed', as well 'making it difficult for private businesses to compete. As indicated by Adnan et al., (2012) conflict of interest is one unethical conduct inside the construction business. This is a circumstance in which somebody in a place of put stock in, for example, a legal advisor, a government official or an official or executive of a company, has contending professional or individual interests which could make it hard to satisfy his or her obligations fairly. Regardless of whether there is no proof of uncalled for activity, an irreconcilable situation can make an appearance of indecency that can undermine trust in the capacity of that individual to act legitimately in his/her position. Irreconcilable situation includes an individual understanding of regardless of whether certain conduct is ordinarily satisfactory, instead of in the event that it is illicit. The onus ought to unmistakably be set upon people to announce every conceivable occurrence of potential antagonistic understanding, before continuing with ventures. Vee and Skitmore's (2003) research proposed that there is a high occurrence of inadmissible conduct in the Australian construction industry. Besides, Supplanting is likewise one of the unethical conduct by Quantity surveyors in the Nigerian construction industry (Babalola and Anifowose, 2015). This is the demonstration of assuming control over another enlisted counseling QS's arrangement as the counseling QS for an undertaking which has been as of now designated by the customer/business and whose arrangement has not been ended or released.

Another unethical conduct by Quantity surveyors in the construction industry is "Bid rigging" and Collusion Tendering. To begin with bidding and tendering process, greater part of the contractual workers get included with bid shopping; which is unethical practice utilized for picking up advantage over the clients (Ameh and Odusami, 2010). At the point when a contractual worker unveils the bid price of one subcontractor to another keeping in mind the end goal to acquire bring down offer value it is known as bid Shopping. It can be worked on amid Pre-award or Post-award of agreement. Collusion tendering is a mystery understanding, particularly for a deceitful reason. Collusion is in opposition to the standards of free rivalry. It benefits just the parties to the tricky assention to the detriment of those not aware of the course of action. Besides, Zarkada-Fraser and Skitmore (2000), noticed it from a financial point of view, collusion erodes the premise and assaults the basis of the aggressive 
competitive tendering system by confining rivalry. The investigation distinguished the interior and outer (ecological and situational) factors that impact the ethical basic leadership process which prompts support in deceitful collusive tendering agreement. The most critical factors are in the outer natural are: regardless of whether I would be held lawfully at risk for the activity, whether there is a lawful issue included. Their exploration shows that the professional's choice whether to wind up engaged with agreement is resolved basically by the lawful ramifications. Conscience was evaluated fourth out of the 25 factors distinguished in the study.

Ehsan et al.(2009) tended to the moral issues confronting the construction industry in Pakistan, from the aftereffects of far reaching and in depth research carried out through poll review, interviews and telephonic study of different partners there was not a solitary individual identified with the construction business who had not encountered some level of unethical direct through; undertaking work beyond capability, bribery, partiality, out of line lead, strict principles, and abrogating of review process over contracting process . Bribery and political debasement is being tended to straightforwardly by a few professional social orders and business bunches far and wide. Quantities of prominent specialists/researchers have examined on this region, this include: Vee and Skitmore, (2003); Aje and Awodele, (2006); Fan et al. (2001); Ehsan et al.(2009); Stanbury (2006); Oladirin and Ho, (2014); Poon, (2004); Nawaz and Ikram, (2013); Inuwa, et al. (2015); Ho, (2013) have all carried out researches on general moral practices among professionals in the construction industry. So far the emphasis on unethical conduct of Quantity surveyors was not completely tended to and the extents of the investigations were not particular. It is a base on this that this exploration will evaluate the level of unethical conduct of Quantity Surveyors on construction industry with a view to improve moral measures among Quantity Surveyors.

\section{METHODOLOGY}

\section{Survey}

The goal of this paper is to explore the present status and to evaluate unethical conduct by Quantity Surveyors in the Nigerian construction industry. Data accumulated by means of a questionnaire survey covering the rundown of unethical practices in the construction industry was observationally tried. In setting up the survey, an audit of ethics among construction professionals' literatures were well attempted. All around organized survey was utilized for the data collection. The survey included determination of honing potential professionals from the accessible postings of professional experts and contractors involved in projects in the investigation territory. The professions represented included Architects, Quantity Surveyors, civil / structural engineers, builders and contractors. A rundown of 21 unethical practices were gotten from literature by Quantity Surveyors in the construction industry which were thusly evaluated on a five-point Likert-type scale with points 1 and 5 representing less common and most common, respectively. Different parts of the questionnaire are intended to assemble demographical data about the respondents. Notwithstanding, because of space impediment, just only analysis of unethical conduct by Quantity Surveyors in the construction business is accounted for in this paper. 


\section{Data Collection}

Purposive sampling procedures was adopted in the choice of the respondent. One hundred and thirty two questionnaire packages were conveyed to the immediate stakeholder on the identified projects. The direct stakeholders are the Quantity surveyors, Architects, Builders and civil/structural engineers including Contractors. Both money related and material motivating forces can be utilized to enhance poll reaction rate (Boyd, 2002), which was adopted during the course of retrieving information from respondents. The total response received was one hundred and fourteen (114) (83\% response rate) this include Quantity surveyors (32.5\% of respondents), Builders (20.2\% of respondents), Architects $(23.7 \%$ of respondents), and Engineers (23.6\% of respondents). Virtually all the respondents (99\%) belong to one or more professional bodies with professional and are duly registered with the irrespective professional bodies. The average working experience of respondents is 13.4 years, this suggests that respondents have adequate experience, hence information provided by the respondents pertaining to unethical issues in the construction industry.

\section{Data Analysis and Results}

Questionnaire data were examined utilizing Statistical Package for the Social Sciences (SPSS 16) to attempt three separate analyse. To begin with, reliability analysis was embraced to decide the consistency of these unethical practices and dependability of the review instrument using Cronbach's $\alpha$ model. From the aftereffect of the analysis, the general Cronbach's $\alpha$ unwavering quality for the 21 practices is 0.865 , showing a worthy interior dependability and consistency of informational index. Distinctive creators have reported about the acceptable values of $\alpha$, running from 0.70 to 0.95 (Tavakol and Dennick, 2011). Secondly, the following analysis positioned the unethical practices in light of mean score value in ranking. In conclusion, the third analysis investigated and arranged the factors for better understanding utilizing factor analysis strategy. Factor analysis has been distinguished as a factual system equipped for recognizing generally modest number of factors as delegates of relationship that exist among numerous interrelated factors (Akintoye, 2000). To separate the fundamental behaviour and explore their structure, the principal component analysis is used in the analysis. Analysis and ranking of unethical behavior by Quantity Surveyors in the construction industry Numerous literatures like Vee and Skitmore, 2003; Ray et al., 1999; May et al., 1999; Fan et al, 2001; Willamson et al., 2004, have demonstrated that most unethical conduct in the construction business appears as out of line direct, carelessness, unfair conduct, negligence, conflict of interest, collusive tendering, fraud and bribery. The mean scores and ranking of all the variables are tabulated in Table I in descending order. As shown in the results, all variables have mean scores ranging from 3.78 to 4.21 , indicating that respondents were generally not in disagreement with the factors contributing to unethical behavior by Quantity Surveyors in the construction industry, only with different extent of agreement. Based on the five-point Likert scale, a factor is deemed "significant" if it has a mean score $\geqslant 3.5$. The factors are ranked based on the mean score values. 
Table 1

Factors

\begin{tabular}{|c|c|c|c|}
\hline Item & Behaviour & Mean & Rank \\
\hline 1 & Supplanting & 4.21 & 1 \\
\hline 2 & Concealing of professional errors & 4.15 & 2 \\
\hline 3 & Conflict of interest & 4.08 & 3 \\
\hline 4 & Insincerity to clients and other professional & 4.07 & 4 \\
\hline 5 & Illegal award to contractor & 4.05 & 5 \\
\hline 6 & Dishonesty and unfair behavior & 4.03 & 6 \\
\hline 7 & Cover pricing & 3.99 & 7 \\
\hline 8 & Disclosure of confidential project baseline & 3.98 & 8 \\
\hline 9 & Bribery & 3.98 & 9 \\
\hline 10 & Fraud & 3.97 & 10 \\
\hline 11 & $\begin{array}{l}\text { Unfair treatment giving to the contractors in tendering/final } \\
\text { account negotiation }\end{array}$ & 3.96 & 11 \\
\hline 12 & Inflating contract sum & 3.94 & 12 \\
\hline 13 & Bid rigging & 3.93 & 13 \\
\hline 14 & Inflating Quantities in BOQ & 3.93 & 14 \\
\hline 15 & Collusive tendering & 3.92 & 15 \\
\hline 16 & Breaches of professional responsibility & 3.85 & 16 \\
\hline 17 & Overbilling and unfair behavior & 3.81 & 17 \\
\hline 18 & Negligence & 3.81 & 18 \\
\hline 19 & $\begin{array}{l}\text { Leaking of information about the project Budget for some } \\
\text { contractors }\end{array}$ & 3.78 & 19 \\
\hline 20 & Qs overstating their qualifications to secure job & 3.78 & 20 \\
\hline 21 & Nepotism & 3.78 & 21 \\
\hline
\end{tabular}

Source: Research Survey, 2017.

The response of professionals who were practicing as consultants or contractors in construction firms, consulting firms and government organizations showed that supplanting $(\mathrm{MS}=4.21)$; concealing of professional errors $(\mathrm{MS}=4.15)$ and conflict of interest $(\mathrm{MS}=$ 4.08) are the most common unethical behaviour and conduct of Quantity Surveyors in their services delivery in the study area. Other highly common unethical behaviour and conduct of Quantity Surveyors were insincerity to clients and other professional (MS = 4.07); illegal award to contractor ( $\mathrm{MS}=4.05$ ); dishonesty and unfair behavior ( $\mathrm{MS}=4.03)$; cover pricing (MS = 3.99); disclosure of confidential project baseline (MS = 3.98); bribery ( $\mathrm{MS}=3.98$ ); fraud (MS = 3.97) and unfair treatment giving to the contractors in tendering/final account negotiation ( $\mathrm{MS}=3.96$ ). The findings agreed with previous studies by Zarkada-Fraser and Skitmore (2001), Zou (2006), Othman (2012), and Nawaz and Ikram (2013) that major notable unethical misconducts in construction industry according to are administrative interference, the illegal award of contracts or subcontracts, exposure of confidential information to certain tenderers and the extortion of kickbacks by client and government 
officials. A portion of the distinguished unethical conduct by Quantity Surveyors in their administrations conveyance in the examination were observed to be less basic as positioned on table I. These conducts were Nepotism (MS = 3.78); Qs overstating their qualifications to secure job (MS = 3.78); leaking of information about the project budget for some contractors (MS = 3.88); negligence (MS = 3.81); overbilling and unfair behavior ( $\mathrm{MS}=3.81$ ); breaches of professional responsibility $(\mathrm{MS}=3.85)$.

\section{Factor Analysis Results}

Factor analysis in evaluating unethical conduct by Quantity Surveyors in their administrations conveyance was likewise attempted. This analysis is proposed to investigate and identify hidden connections among the unethical behaviours, and depict them in less, however in more compact and thorough factors. Principal components analysis requires that there be connections esteems more prominent than 0.30 between the factors incorporated into the analysis (Yang et al., 2009). In the event that no connections go past 0.30 , at that point the researcher ought to reevaluate whether factor analysis is the fitting measurable technique to use (Williams et al., 2010). The aftereffect of this investigation demonstrates a few connections more noteworthy than the prescribed edge of 0.3 proposing reasonableness of the information for information analysis. To use factor analysis, it is vital to learn whether the information are reasonable. Test to variable proportion is prescribed to decide information appropriateness (Williams et al., 2010). Factor analysis system expected cases to variable proportion of 1:5 (Lingard and Rowlinson, 2006). Factor analysis of unethical conduct of Quantity Surveyors in the examination zone was embraced. This analysis is planned to investigate and recognize fundamental connections among the factors, and portray them in less, however in more brief and complete factors. The noteworthy factors with MS $\geq 3.00$ were lessened to main parts with factor analysis as utilized by khalid (2010) and Yap (2013). For sampling adequacy test, the Kaiser-Meyer-Olkin (KMO, 0.874) in Table II demonstrated that information gathered were sufficient for the analysis and the Bartlett's test of sphericity for connections ampleness between the factors was exceptionally noteworthy. Kaiser-MeyerOlkin (KMO) Measure of inspecting ampleness of information gather on unethical conduct by Quantity Surveyors. The KMO clarifies that $87.4 \%$ of the information accumulated were satisfactory and it clarifies how suited the information is for factor analysis. It measure the sampling adequacy for every factor considered and the entire model on unethical practices by Quantity Surveyors. Since the esteem extends between $0.874(87.4 \%)$ shows that the inspecting is sufficient for factor analysis. Barlett's Test of Sphericity demonstrates whether an information or the sampling considered can be appropriate for factor analysis. Haven't played out the analysis, it could be demonstrated that the $\mathrm{P}$ - value considered is $<0.05$ which infers that the information is reasonable for factor analysis with level of freedom of 210 and an estimated chi - square of 615.835 . For this information, Barlett's test is profoundly critical (P-value $=0.000)$, recommending that the connection is a personality lattice which implies that the relationship grid demonstrates that every one of the things recorded have huge relationship at the 5\% level and consequently exploratory factor analysis is suitable. The result in Table II shows varimax orthogonal rotation of principal component for interpreting these unethical behaviours. The naming is subjective. It depends on the background and 
training of the analyst. There is no specific scientific procedure for naming the behaviours. Therefore, the thoughtful naming of these behaviours were deemed to be appropriate for this study. The unethical behaviours and the associated variables are interpreted as follows: i) dishonesty, ii) insincerity, iii) financial mismanagement, iv) information leaking, v) Negligence, and vi) conflict of interest.

Table 2

Factor Analysis

\begin{tabular}{|c|c|c|c|c|c|c|c|}
\hline \multirow[t]{2}{*}{ Unethical behavior } & \multicolumn{6}{|c|}{ Component } & \multirow[t]{2}{*}{ Com } \\
\hline & $\overline{\text { F1 }}$ & $\overline{F 2}$ & $\overline{\text { F3 }}$ & $\overline{\text { F4 }}$ & $\overline{\text { F5 }}$ & $\overline{\text { F6 }}$ & \\
\hline Breaches of professional responsibility & .706 & & & & & & .559 \\
\hline Dishonesty and unfair behavior & .653 & & & & & & .540 \\
\hline Fraud & .582 & & & & & & .496 \\
\hline Overbilling and unfair behavior & .536 & & & & & & .719 \\
\hline Qs overstating their qualifications to secure job & & .728 & & & & & .756 \\
\hline Bribery & & .686 & & & & & .717 \\
\hline Cover pricing & & .646 & & & & & 690 \\
\hline Insincerity to clients and other professional & & .577 & & & & & .747 \\
\hline Supplanting & & .549 & & & & & .443 \\
\hline Disclosure of confidential project baseline & & .494 & & & & & .615 \\
\hline $\begin{array}{l}\text { Unfair treatment giving to the contractors in } \\
\text { Tendering/final account negotiation }\end{array}$ & & & .787 & & & & .769 \\
\hline Inflating Quantities in BOQ & & & .614 & & & & .758 \\
\hline Bid rigging & & & .511 & & & & 671 \\
\hline $\begin{array}{l}\text { Leaking of information about the project budget } \\
\text { for some contractors }\end{array}$ & & & & .711 & & & .755 \\
\hline Concealing of professional errors & & & & .689 & & & 686 \\
\hline Illegal award to contractor & & & & .549 & & & .830 \\
\hline Collusive tendering & & & & & .697 & & .631 \\
\hline Negligence & & & & & .466 & & .692 \\
\hline Inflating contract sum & & & & & .439 & & .584 \\
\hline Conflict of interest & & & & & & .850 & .760 \\
\hline Nepotism & & & & & & .513 & .616 \\
\hline Percentage of variance explained & 21.587 & 9.307 & 7.328 & 6.939 & 5.919 & 5.553 & \\
\hline Cumulative variance $\%$ & 21.587 & 30.894 & 38.222 & 45.161 & 51.080 & 56.633 & \\
\hline Kaiser-Meyer-Olkin Measure of Sampling & .874 & & & & & & \\
\hline Adequacy. & Approx. & Chi-Square & & & 615.837 & & \\
\hline \multirow[t]{2}{*}{ Bartlett's Test of Sphericity } & & & & & & & \\
\hline & $\begin{array}{c}\text { Df } \\
\text { Sig. }\end{array}$ & & & & $\begin{array}{l}210 \\
.000\end{array}$ & & \\
\hline
\end{tabular}

DISCUSSION OF RESULTS 


\section{1: Dishonesty}

Dishonesty, being the first component explained that this principal factor accounts $(21.59$ per cent). This is by all accounts the most well-known unethical conduct by Quantity Surveyors in their administrations conveyance in the construction industry. It shocks no one to see trustworthiness at the highest point of the announcement of moral standards. As the international studies illustrated, the industry has an exceptionally poor record and notoriety in such manner. Cases of dishonest behaviour by Quantity Surveyors in the Nigerian construction industry are given as pay off, claims extortion, claims fraud, collusive tendering, kickbacks and the preparation of forged documents to support claims. The issues of the relatively unlimited potential outcomes for dishonest behaviour are exacerbated by the high plausibility of escaping with it. Dishonest, in the form of corruption or illegal behavior, is viewed as a developing test for construction organizations and society everywhere (Transparency International, 2009). Vee and Skitmore (2003) consolidate injustice with contemptibility which was contended that untruthfulness constitutes illicit conduct and is in this way more suitably connected to fraud. Bologna, Linquist and Wells (1996) depicted dishonesty nature as being misdirection, fraud, sharp practice or a rupture of certainty, by which it is looked to increase some unreasonable or untrustworthy preferred standpoint. The qualification is apparent between a demonstration that is unlawful and that which might be deciphered as 'unfair conduct'. A commonplace case of this would incorporate altering/modifying documents for the legally and contractual administration of a project by Quantity Surveyors when rendering their services delivery. In addition, this component (dishonesty) featured five unethical practices which are: breaches of professional responsibility, dishonesty and unfair behavior, fraud, overbilling and unfair behavior. Those that received higher loading are: Breaches of professional responsibility, dishonesty and unfair behavior, fraud are regarded as the major unethical behaviour and conducts of Nigerian Quantity Surveyors. This discoveries bolster the situation of Camerer (2001) and Pearl et al., (2005) that despite the ability of construction industry to convey the most inventive and complex activities, ethics inside the construction industry has turned into the focal point of consideration for many built environment professionals with the most corrupt/degenerate conduct, extending from agreement, ruptures of professional duty and bribery to misrepresentation.

\section{2: Insincerity}

The second principal behaviour is marked "Insincerity/Untrustworthiness". As appeared in Table II, this behaviour represents $9.31 \%$ of the aggregate observed variance and contains six embedded unethical practices which can be viewed to as "insincerity" in the quantity surveying profession. These are: Qs overstating their qualifications to secure job, bribery, cover pricing, insincerity to clients and other professional, supplanting and disclosure of confidential project baseline. In addition, pattern of Cover pricing' by QS has brought cautions step up in the construction industry. In this procedure in construction industry, a bidder presents a value that isn't expected to win the agreement they are participating. There are different manners by which contending bidders practice this negligence. It is possible that they submit cushioned up offer which is unimaginable for the acknowledgment, or thump out 
assigned victor or oblige such terms and conditions that are known to be unsatisfactory to the clients [Oyewobi et al. (2011) and Olusegun et al. (2011]. As indicated by Okpala (2002), a basic industry like the constructions industry ingests disinvestments coming about because of intemperate bribe and Insincerity /Untrustworthiness which described the Nigerian leadership since the finish of the civil war. Powpaka (2002) contended that Insincerity /Untrustworthiness turns into a moral issue instead of a legitimate issue where there is either a general absence of law to indict those occupied with pay off or where there is law however it isn't being utilized as frequently as it not completely enfored. Findings buttress the position of Nawaz and Ikram, 2013; Abdul-Rahmam et al. (2011); Hamzah et al. (2010); Aigbavboa et al. (2016) that striking among unethical conduct among construction professional are renumeration and misrepresentation, adulteration of experience, nepotism, unlawful honor of tender, deceitful offering and exaggeration of capability/preparing to secure employment.

\section{3: Financial Mismanagement}

The third principal behaviour is categorized as financial mismanagement. Quantity surveyors are ultimately responsible for the financial management of a construction company. Regularly (particularly in littler construction organizations) a significant number of these errands are designated to junior estimators, secretary, or project managers especially those assignments that are strictly medium size projects. For this reason, numerous Project administrators, Directors, Estimators and Quantity surveyors try to climb inside the organization or begin their own construction business, it is vital for all Quantity surveyors to comprehend the standards of budgetary accomplishment for a construction organization not enabling unethical wrongdoing/ misconduct to lead them to money related blunder with has been common within Nigerian construction industry. The financial mismanagement factor accounts for $7.33 \%$ of the total observed variance and contain three items. The reported factor loadings for the variables are; unfair treatment giving to the contractors in tendering/final account negotiation, inflating quantities in BOQ, and bid rigging. To begin with bidding and tendering process, larger part of the Nigerian Quantity surveyors get included with bid shopping; which is unethical practice utilized for picking up advantage over the clients (Ameh and Odusami, 2010).

\section{4: Information Leaking}

The fourth principal behaviour is tagged "Information leaking". This behaviour is viewed as extremely significant passing by the general rating demonstrated in Table II. It likewise contains three embedded unethical practices and records for $6.94 \%$ of the total observed variance. The practices listed in this principal behaviour are: Leaking of information about the project budget for some contractors, Concealing of professional errors, Illegal award to contractor. As talked about before, this gathering additionally concurred with past investigations by Zarkada-Fraser and Skitmore (2001), Zou (2006), Othman (2012), and Nawaz and Ikram (2013) that significant prominent unethical unfortunate activities in construction industry as indicated by are authoritative impedance, the unlawful honor of agreements or subcontracts, the introduction of private data to certain givers and the blackmail of kickbacks by customer and government authorities.

\section{5: Negligence}


The fifth principal behavior is tagged "Negligence" which contains collusive tendering, negligence, and inflating contract sum. It represents $5.9 \%$ of the aggregate total observed variance. Negligence/Carelessness as 'absence of appropriate care and consideration; or lack of regard's' is additionally one of the unethical conduct by Quantity surveyors in the Nigerian construction industry. Professionally, this would be the inability to practice the level of care considered sensibly justified by the conditions, bringing about unintended damage to another parties [Abdul-Rahmam et al. (2011); Bowen et al.,(2007); Aje and Awodele, (2006)]. Another unethical practices embedded under Negligence in this finding by Quantity surveyors is "collusion tendering", which is a mystery seeing, particularly for a deceitful reason'. Conspiracy is in opposition to the standards of free rivalry in the construction industry. As per Nawaz and Ikram, (2013), to be careless/ negligent, the professional probably had the capacity to be able, yet has ignored the essential significance of practicing this capacity.

\section{6: Conflict of Interest}

The last principal behavior is titled "conflict of interest" which comprises of conflict of interest and nepotism. This accounts for $5.3 \%$ of the total observed variance. Conflict of interest is one the normal unethical conduct by Quantity surveyors in Nigeria construction industry. As indicated by Adnan et al., (2012), conflict of interest is one unethical conduct inside the construction industry in which somebody in a place/position of trust, for example, a Quantity surveyor, a temporary worker or a planner, a contractor or an architect, has contending professional or individual interests which could make it hard to satisfy his or her obligations fairly. Regardless of whether there is no proof of despicable activity, a conflict of interest can make an appearance of indecency that can undermine trust in the capacity of that individual to act legitimately in his/her position. Conflict of interest includes an individual understanding of regardless of whether certain conduct is generally worthy, as opposed to on the off chance that it is illicit. The onus ought to plainly be set upon people to pronounce every conceivable occasion of potential adverse translation, before continuing with ventures. Vee and Skitmore's (2003) study suggested that there is a high occurrence of unsatisfactory conduct of this write in the Australian construction industry.

\section{SUMMARY, CONCLUSIONS AND RECOMMENDATIONS}

Construction projects have experienced under-accomplishment in the past, this is on the grounds that professional's wrongdoing has been on the expansion in the industry. Despite the fact that the construction business is one of the key drivers of financial development in Nigeria, the industry faces a not insignificant rundown of moral difficulties identified with conduct from its professionals. The feeling study of this report demonstrated that there are basic conduct of concern with respect to unethical practices among Quantity surveyors in Nigerian construction industry. Despite the different codes of professional conduct, the scope of moral issues evident incorporates plot, pay off, carelessness, collusion, bribery, negligence, fraud, dishonesty and unfair practices. Findings on it demonstrated that supplanting, concealing of professional error and dishonesty \& unfair behavior were most common unethical behaviour and conduct of Quantity Surveyors in the industry. The unethical conduct of Quantity Surveyors distinguished in literature were all normal among Quantity Surveyors 
in the investigation zone. There were little contradiction among the professionals within the Nigerian construction industry on the positioning of highest unethical conduct of Quantity Surveyors which is supplanting. In addition, factor analysis reduces these unethical behaviour and showed that dishonesty, insincerity, financial mismanagement, information leaking, negligence, and conflict of interest were the component item of unethical behaviour and conduct of Quantity Surveyors in the study area.

From the research findings, it is clear that plainly, ethical issues are exceptionally imperative in the achievement and improvement of the construction industry. The methodology employed in this study can be imitated by other professionals like the Architect, Contractors, Builders and the Engineers within the Nigerian construction industry. This can also be replicated in other locations for further studies. Moreover, further studies may use more methods in collected the data. For this study, only questionnaire survey is used, using several methods the results will be more flexible and precise data. Method such as interview, comparing data and many more should be adopted. Such studies may investigate the relationships between the principal behaviour and their associated behaviours. While this investigation has given helpful information with respect to unethical conduct by Quantity Surveyors, the confinement is inalienable in the number of respondents of the study which is constrained to the exploration region. The study recommends the enforcement of the code of conduct among Quantity Surveyors; appropriate disciplinary move must be made by relevant authorities once unethical behaviour is revealed; offenders should be banned from practicing; conducting workshops with respect to professional code of conduct; universities, colleges and other professionals institutions ought to present ethics instruction as a major subject; and professional bodies (NIQS and QSRBN) should try to present private announcing framework. Subsequently, there is require that legitimate activity to uphold the code of conduct must be taken by applicable experts and professional bodies (NIQS and QSRBN) to guarantee follow.

\section{Reference}

Abdul-Rahman, H., Hanid, M., \& Yap, X. W. (2014). Does professional ethics affect quality of construction-a case in a developing economy? Total Quality Management \& Business Excellence. 25(3-4), 235-248.

Adnan H., Hashim N., Mohd, N., \& Yusuwan, N, (2012). Ethical Issues in the ConstructionIndustry: Contractor's Perspective. Procedia - Social and Behavioral Sciences, 35, 719.

Aigbavboa C., Oke, A, \& Tyali, S. (2016). Unethical Practices in the South African Construction Industry. 5th Construction Management Conference Department of Construction Management Nelson Mandela Metropolitan University.

Aje, I. O, \& Awodele, O. A. (2006). Study of Ethical Values of Quantity Surveyors in Nigeria; Ethical Issues and the challenges in Construction Professionals Service Delivery, Proceedings of a 2-Day NIQS National Seminar. pp 2-3.

Ameh, O. J., \& Odusami, K. T. (2010). Professionals 'ambivalence towards ethics in the Nigerian construction industry. Journal of Professional Issue in Engineering Education and Practice, 36(1), 9-16. 
Amundsen, I., Sissener, T., Soreide, T. (2000). Research on Corruption: A Policy Oriented Survey. Chr. Michelsen Institute (CMI) \& Norwegian Institute of InternationalAffairs, Oslo/Bergen

Babalola, A. A, \& Anifowose, O. S. (2015). A Study of the Compliance of Practising Quantity Surveyors with the Professional Code of Conduct in Nigeria. IOSR Journal Of Humanities and Social Science (IOSR-JHSS) 20(3),16-20.

Bologna, G., Linquist, R. \& Wells, J. (1996). Fraud and Commercial Crime. John Wiley \& Sons, FreybPress: Sydney

Bowen P., Akintoye A., Pearl R, \& Edwards P. J. (2007). Ethical behaviour in the South African construction industry. Construction Management and Economics, 25(5), 631648.

Boyd, H.H. (2002). How to Get a Respectable Response Rate, University of WisconsinExtension, Madison, WI, available at: www.uwex.edu/ces/pdande/resources/quicktipsnumerical.html (accessed 2 April 2014).

Brandon, P.S. (1990). Quantity Surveying Techniques: New Direction - The Challenge and the Response. In: Brandon, P.S. (editor) Quantity Surveying Techniques: New Direction, Blackwell Science Ltd. London, 1- 20.

Camerer, L. (2001). Corruption in South Africa: results of an expert panel survey. Institute o fStrategic Studies (ISS). Retrieved 2009, from Criminal Justice Monitor: <www.iss.co.za/index.php?link_id53\&slink_id5442\&link_type512\& slink_type512\&tmpl_id53>

Ehsan, N., Anwar, S., \& Talha, M. (2009). Professional ethics in construction industry of Pakistan. In Ao, S. I., Douglas, C., Grundfest W. \& Burgstone, J., Proceedings of the World Congress on Engineering, 20 - 29 October, San Francisco, USA, pp. 1-5.

Fan, L., Ho, C. \& Vincent, NG. (2001). A study of quantity surveyors' ethical behaviour in Construction Management and Economics, 19, 19-36.

Hamimah, A., Norfashiha, H., Norazian, M., Yusuwan, N. (2012). Ethical Issues in the Construction Industry: Contractor's Perspective. Procedia-Social and Behavioral Sciences, 35, 719-727.

Hamra, W. (2000). Bribery in International Business Transactions and the OECD Convention. Business Economics, 35(4), 33- 46.

Hamzah, A., Wang, C., \& Yap, X. (2010). How professional ethics impact construction quality: perception and evidence in a fast developing economy. Scientific research and essays, 5(23), 3742-3749.

Ho, M. F. (2011). Ethics management for the construction industry: A review of ethical decision making literature. Engineering, Construction and Architectural Management, 18(5), 516-537.

Inuwa, I.I., Usman, N.D., \& Dantong, J.S. (2015). The Effects of Unethical Professional Practice on Construction Projects Performance in Nigeri. African Journal of Applied Research, 1(1), 72-88. 
Khalid, M. S. (2010). Abandoned housing development: the Malaysian experience (a PhD Thesis submitted to School of Built Environment, Heriot-Watt University, Edinburgh). Retrieved from http://www.ros.hw.ac.uk/handle/10399/2321.

Lingard, H., \& Rowlinson, S.M. (2006). Occupational health and safety in construction project management, London: Taylor and Francis

Mathenge, G. (2000). Ethical Issues in the Construction Industry in Kenya: A Critical Analysis of the Professional Conduct in Engineering Technology Management. Industrial Engineering Letters, 2(7), 2012.

Mason, J. (2009). Ethics in the construction industry: the prospects for a single professional code. International Journal of Law in the Built Environment, 1(3), 194-204.

May, D., Wilson, O.D., \& Skitmore, R.M. (2001). Bid cutting: an empirical study of practice in south-east Queensland. Engineering, Construction and Architectural Management, $8(4), \quad 250-6$

Miller, D. (2011). Improve poor ethics in construction: set consequences, Colorado Real Estate Journal online. (Accessed on 25th July 2017).

Mondejar, R., Cheung, S.,\& Suen, H. (2007). Teaching and learning ethics: the construction manager's perspective, CIB world building congress, Cape Town, South Africa.

Nawaz, T., \& Ikram, A. (2013). Unethical Practices in Pakistani Construction Industry European Journal of Business and Management, 5(4), 2-4

Nkado, R., \& Meyer, T. (2001). Competencies of professional quantity surveyors: South African perspective. Construction Management and Economics, 19, 481-491

Okpala, D. C. (2002). Funding a viable Nigeria Construction Industry In the 21st century (New Institutional Framework). Nigerian Journal of Construction Management, 3(1), 33-44.

Oladinrin, T., \& Ho, C. (2014). Strategies for Improving Codes of Ethics Implementation in Construction Organizations. Project Management Journal, 45(5), 15-26.

Olusegun, A., Benson, O., Esther, A., \& Michael, A. (2011). Corruption in the construction industry of Nigeria: causes and solutions, Journal of Emerging Trends in Economics and Management Sciences, 2(3), 156-159.

Othman, A.E. (2012). An innovative protocol for improving the ethical behavior of the Quantity surveying profession in South Africa. International Journal of Construction Management, 12(3), 43-62.

Oyewobi, L. O., Ganiyu, B. O., Oke, A. A., Ola- Awo, A. W., \& Shittu, A. A. (2011).Determinants of unethical performance in the Nigerian construction industry. Journal of Sustainable Development, 4(4), 175-182.

Paswan, R. K, (2010). Role of Ethics in Modern Business: An Important Key Aspect of the Concern

Pearl, R, Bowen, P, Makanjee, N, Akintoye, A., Evans, K. (2005). Professional ethics in the South African construction industry - a pilot study, in front outback - conference proceeding, Austrailian universities building educators association, Brisbance, 11-12

Poon, J. (2004). The Study of Ethical Behaviour of Surveyors. Paper presented to COBRA, $20047-8$ September, Leeds. 
Powpaka, S. (2002). Factors affecting managers decision to bribe: an empirical investigation. Journal of Business Ethics, 40, 227-46.

RICS. (2001). Professional Ethics Guidance Note: Part 1 Introduction, RICS Professional Regulation and Consumer Protection Department, London pp.1.

Robinson, S., Dixon, J.R., Preece, C.N., \& Moodley, K. (2007). Engineering, Business and Professional Ethics, 7(3), 9-15.

Rosenthal, R., Rosnow, R. L. (1991). Essentials of Behavioral Research: methods and data analysis (2nd edn.), Boston, Mass.: McGraw-Hill.

Stansbury, N. (2006). 'Business not as usual', a paper published by the chartered Institute of Builders, 3rd Quarter, pp. 3-8.

Uff, J. (2006). Ethics in Construction law - two years on' Australian Construction Law Newsletter \# 106, February 2016

Vee, C., \& Skitmore, M. (2003). Professional ethics in the construction industry. Engineering, Construction and Architectural Management, 10(2), 117- 27.

Wasserman, B. (2000). Ethics and Practice of Architecture. New York, McGraw-Hill

Williamson, M., Wilson, O.D., Skitmore, R.M. and Runeson, G. (2004) Client abuses of the competitive tendering system: some general principles and a case study. Journal of Construction Research, 5(1), 61-74

Yang, J., Shen, G.Q.P., Ho, M.F., Drew, D.S. and Chan, A.P.C. (2009). Exploring critical success factors for stakeholder management in construction projects. Journal of Civil Engineering and Management, 15(4), 337-348.

Yap, E. H. (2013). Causes of abandoned construction projects in Malaysia (MSc. Dissertation, Department of Surveying, Faculty of Engineering and Science, Universiti Tunku Abdul Rahman, 2013).

Zarkada-Fraser, A., \& Skitmore, R. M. (2000). Decisions with moral content: Collusion. Construction Management and Economics, 18(1), 101-111.

Zou, P. X. (2006). Strategies for minimizing corruption in the construction industry in China. Journal of Construction in Developing Countries, 11(2), 15-29. 